date at about $240,000 \mathrm{yr}$ BP. Thus although the Arctic speleothem dates support the climatic marine implications of isotope stage 7 they are not ideal for discriminating between events on either side of stage $7 \mathrm{~b}$.

Variations in ocean level should be a first-order monitor of global ice volume, and although these records are more complex than had been thought ${ }^{6}$, they should be accurate enough for our purpose. Raised coral reef and submerged coastal speleothem records from subtropical and tropical sites ${ }^{7}$ do indicate two distinct high sea levels, at 200,000 and $230,000 \mathrm{yr} \mathrm{BP}$, separated by an interval of low sea level. These data may thus serve to strengthen the arguments advanced by Ruddiman and McIntyre, although the actual date of the earlier sea-level high coincides with the postulated ice-growth events.

The remarkable speed of glaciation and deglaciation implied by the deep-sea record of stage $7 \mathrm{~b}$ raises once again the question of how rapidly the world can proceed from an interglacial to a glacial mode. Ruddiman and McIntyre suggest that significant storage of continental glacier ice (possibly 30-60 per cent of the Late Wisconsin glacial 'maximum' at 18,000 yr BP) occurred in about $10,000 \mathrm{yr}$ while the return to interglacial values occupied only 7,000 yr. Glaciological modelling of ice-sheet growth over North America for the last 125,000 yr BP has been attempted by Budd and $\mathrm{Smith}^{8}$, who use Milankovitch orbital variations combined with a relatively sophisticated glaciological model to investigate the extent and timing of ice-sheet growth for the Laurentide Ice Sheet. The process was found to be dominated by the 40,000 yr Milankovitch period - a finding partly supported by new evidence on the glacial history of Hudson Bay ${ }^{9}$ which suggests that complete glaciation and deglaciation of the geographical centre of the Laurentide Ice Sheet may indeed have occurred during the Last (Wisconsin) Glaciation.

But the evidence of Ruddiman and McIntyre requires processes to operate at twice that rate. How this might be accomplished climatologically and glaciologically is a moot point, but one that deserves serious consideration. Their paper should encourage detailed investigations into events during marine isotope stage 7 and the penultimate interglacial record on land.

J.T. Andrews is Professor in the Department of Geological Sciences and INSTAAR, Univesity of Colorado, Boulder, Colorado 80309.

\footnotetext{
Ruddiman, W.F. \& McIntyre, A. Bull. geol. Soc. Amer 93, 1273 (1982).

2. Emiliani, C. J. Geol. 63, 538 (1955).

3. Shackleton, N.J. \& Opdyke, N.D. Ouat. Res. 3, 39 (1973).

Bowen, D.Q. Quaternary Geology 221 (Pergamon, New York, 1978).

Harmon, R.W el al Can J. Earth Sci, 14, 2543 (1977).

6. Clark, J.A. el al. Quat. Res. 9, 265 (1978).

6. Clark, J.A. el al. Quat. Res. 9, 265 (1978).
7. Harmon, R.S. GeoAhsiracts (cd. Mahancy, W.C.) 299. 318 (Norwich, 1981).

8. Budd, W.F. \& Smith, I.N. Int. Ass. Sci. Hydrol. 131, 44 I (1982).
}

9. Andrews, J.T. et al. Quat. Res. 19, 18 (1983).

Obituary

Charles Heidelberger, 1920-1983:
research on cancer chemotherapy

\title{
from Peter Brookes
}

Charles Heidelberger, Distinguished Professor of Biochemistry and Pathology and Director for Basic Research at the University of Southern California Cancer Center, Los Angeles, died on 18 January 1983, aged 62.

Charles Heidelberger studied chemistry at Harvard where he remained to work for his PhD in the laboratory of Professor Louis F. Fieser. He was no doubt exposed to that laboratory's enthusiasm for chemical carcinogenesis, although war-time emergencies had resulted in a temporary halt to this work. After a period in Professor Melvin Calvin's laboratory in Berkeley, where he became skilled in the synthesis of radioactively labelled compounds, Heidelberger joined in 1948 the recently established McArdle Laboratory in Madison, Wisconsin, where he remained for the following 28 years.

Charles Heidelberger devoted his entire working life to cancer research and made internationally recognized contributions in the areas of carcinogenesis and chemotherapy.

His early work involved the study of the metabolism of polycyclic hydrocarbons made possible by his synthesis of such compounds labelled with carbon-14. When he recognized that such studies were telling him more about detoxification than mechanisms of carcinogenesis he concentrated on the binding of carcinogens to cellular macromolecules and in particular the soluble proteins of mouse skin. He found for a series of hydrocarbons a good correlation between protein binding and carcinogenic activity; the only notable exception being for 1,2,3,4-dibenzanthracene. He realized that this apparent anomaly might allow him to identify the particular protein fraction most relevant to carcinogenesis and therefore initiated an extensive study of protein fractionation. This led to the identification of a class of skin proteins similar to the h-proteins reported by others to bind liver carcinogens. However despite considerable effort the significance of this protein binding remains undetermined.

While engaged in the above research Heidelberger became interested in the potential benefits to cancer patients of chemotherapy. He noted that uracil was used more efficiently by tumours than by normal cells. He therefore synthesized an analogue of uracil having fluorine in the 5 position, which would be expected to block its conversion to thymine, required for DNA synthesis. He was able to show that 5-fluorouracil (5-FU) was active against a series of transplanted rodent tumours and subsequently its value as a clinically useful drug was confirmed. In later studies it was established that 5-FU was converted to the 2 '-deoxyribonucleotide which was a potent inhibitor of thymidylate synthetase. Among many other fluorimated pyrimidines prepared in Heidelberger's laboratory, 5-trifluoromethylthymidine was shown to have powerful activity against several DNA viruses, including herpes simplex of the eye.

Recognizing the limitations of carcinogenicity studies in vivo, Heidelbeger initiated work to develop a system of mammalian cell transformation in vitro. In his early experiments he used organ cultures of $\mathrm{C} 3 \mathrm{H}$ mouse prostate, and when this failed to give tumours on reimplantation, he prepared cell cultures from the carcinogen-treated prostate. In this way permanent cell lines were established which did yield tumours when injected into $\mathrm{C} 3 \mathrm{H}$ mice. Subsequent developments involved an aneuploid $\mathrm{C} 3 \mathrm{H}$ cell line in a focus assay, and later a $\mathrm{C} 3 \mathrm{H}$ line obtained by plating $0.5 \times 10^{6}$ cells per dish and transferring the cells every 10 days, following the procedure used by Aaronson and Todaro in establishing the BALB 3T3 line. By analogy this line was designated $\mathrm{C} 3 \mathrm{H} 10 \mathrm{~T} 1 / 2$, and shown to possess high post-confluence inhibition of growth and to have a very low transformation frequency. On treatment with carcinogen, readily recognized piled-up foci were produced, and this enabled the cell to be used in studies of tumour initiation and promotion.

Charles Heidelberger received many honours and distinctions. He was elected to the US National Academy of Science in 1978 and in September 1982 was the first awardee of the Athayde Cancer Prize. He was nominated as ' 1982 man of the year' by the American Cancer Society.

Heidelberger moved from Madison to Los Angeles in 1976 to help develop the new cancer center. He died without seeing the completion of this plan, but his contribution to this project in cancer research will long be remembered.

Peter Brookes is Head of the Division of Chemical Carcinogenesis at the Institute of Cancer Research, Pollards Wood Research Station, Chalfont St Giles, Bucks HP8 4SP. 